\title{
PENGARUH KOMPETENSI MENGAJAR GURU DAN POLA ASUH ORANG TUA TERHADAP KONSEP DIRI DAN MOTIVASI BERPRESTASI SISWA SD KELAS VI
}

\author{
Reflina Sinaga \\ Dosen UNIKA Sumatera Utara \\ Surel : sinagareflina@yahoo.co.id
}

\begin{abstract}
Abstrak
Penelitian ini menggunakan salah satu bentuk dari Probability Sampling yaitu simple random sampling. Untuk skala kompetensi mengajar guru, pola asuh orang tua terlebih dahulu di uji cobakan sedangkan skala Motivasi Berprestasi diadaptasi dari "Measuring Achievement Motivation. Hasil pengujian menunjukkan bahwa Pengaruh kompetensi mengajar guru terhadap motivasi berprestasi secara langsung sebesar $0,408=40,8 \%$, hal ini terlihat pada nilai sig. 0,000. $(0,000 \leq 0,05)$. Pengaruh pola asuh orang tua terhadap motivasi berprestasi secara langsung sebesar $0,266=26,6 \%$, hal ini terlihat pada nilai sig. 0,000 . $(0,00 \leq 0,05)$. Pengaruh tidak langsung kompetensi mengajar guru terhadap motivasi berprestasi melalui konsep diri sebesar $0,083=8,3 \%$. Pengaruh tidak langsung pola asuh orang tua terhadap motivasi berprestasi melalui konsep diri sebesar $0,054=5,4 \%$. Pengaruh konsep diri terhadap motivasi berprestasi sebesar $0,204=2,04 \%$, hal ini terlihat pada nilai sig. $0,000 .(0,05 \leq 0,000)$.
\end{abstract}

Kata Kunci: Kompetensi Mengajar, Pola Asuh, Konsep Diri.

\section{PENDAHULUAN}

Perbincangan tentang rendahnya mutu pendidikan di Indonesia bukanlah merupakan hal baru bagi sebagian masyarakat Indonesia. Sampai saat ini belum ada solusi yang tepat dalam mengatasi rendahnya mutu pendidikan di Indonesia. Berdasarkan hasil survey yang dilakukan oleh The Asian-South Bureau of adult Education and The Global Campaign for Education, menunjukkan bahwa Indonesia hanya mampu menduduki ranking 10 dari 14 negara di kawasan Asia Pasifik. Jika dikalkulasikan Indonesia hanya mencapai angka 42 dari 100 skor maksimal atau mendapat nilai $\mathrm{E}$ dalam komitmen kepada pendidikan dasar. Sedangkan Thailand dan Malaysia menduduki nilai A, yang kemudian diikuti oleh Srilanka dengan nilai B. Sedangkan Filipina, Cina, Vietnam, Bangladesh, Kampuchea, dan India mendapat nilai C. Indonesia lebih baik hanya dibandingkan dengan Nepal, Papua Nugini, Kepulauan Solomon, dan Pakistan (Sondakh, 2008).

Menurut catatan Depdiknas, dari 1.141.168 guru SD se-Indonesia, ternyata baru $38 \%$ atau 442.310 guru saja yang memenuhi syarat layak mengajar. Mereka dikatakan tidak layak mengajar karena ijazah yang dimiliki di bawah jenjang D2 sehingga diasumsikan kreativitas, daya nalar, penguasaan ilmu dan 
kemampuan mengajar di kelas masih belum berkembang secara maksimal. Bahkan bagi guru-guru yang telah menempuh program penyetaraan dan memperoleh gelar D2 sekalipun tidak menunjukkan peningkatan kemampuan yang signifikan dalam mengajar di kelas (Harian Kompas, 2005).

Menurut Chaplin (2000)
dijelaskan bahwa pengertian
motivasi yaitu: (1) Dorongan untuk
berbuat atau beraksi (2)

Menjalankan tugas sebagai satu insentif atau sebagai satu tujuan. Motivasi berprestasi adalah suatu dorongan dari dalam diri seseorang, sehingga selalu berusaha untuk dapat meningkatkan atau mempertahankan kemampuannya semaksimal mungkin. Kebutuhan untuk berprestasi tersebut menjadikan seseorang akan selalu berusaha untuk lebih baik daripada orang lain dalam melaksankan tugas, pengabdian, berusaha untuk memenuhi kebutuhan untuk dapat berprestasi guna menyamakan diri dengan prestasi orang lain. Motivasi berprestasi dapat membuat seseorang menjadi pribadi yang berhasil dan bertanggung jawabatas tugas-tugas yang dipercayakan kepadanya.

Kompetensi mengajar guru adalah salah satu faktor yang mempengaruhi tercapainya dan tujuan pembelajaran dan pendidikan di sekolah, namun kompetensi guru tidak berdiri sendiri tetapi dipengaruhi oleh faktor latar belakang pendidikan, pengalaman mengajar, dan lamanya mengajar.
Konsep diri terbentuk melalui proses belajar sejak masa pertumbuhan dari kecil hingga dewasa. Lingkungan, pengalaman, dan pola asuh orang tua turut memberikan pengaruh yang signifikan terhadap konsep diri yang terbentuk. Sikap atau respon orang tua dan lingkungan akan menjadi bahan informasi bagi anak untuk menilai siapa dirinya.

Konsep diri dapat didefenisikan secara umum sebagai keyakinan, pandangan atau penilaian seseorang terhadap dirinya.

Keluarga yang utuh memberikan peluang besar bagi anak untuk membangun kepercayaan terhadap kedua orang tuanya, yang merupakan unsur dasar dalam membantu anak untuk memiliki dan mengembangkan dasar-dasar disiplin diri (Schochib, 1998).

Menurut Hurlock (1980) masa kanak-kanak dimulai setelah melewati masa bayi yang penuh ketergantungan, yakni kira-kira usia dua tahun sampai saat anak matang secara seksual atau sekitar tiga belas tahun untuk wanita dan empat belas tahun untuk laki-laki. Masa kanakkanak harus dibagi lagi menjadi dua periode yang berbeda-awal dan akhir masa kanak-kanak. Periode awal berlangsung dari umur dua sampai enam tahun dan peride akhir dari enam sampai tiba saatnya anak matang secara seksual.

Penelitian ini bertujuan:

a) Untuk mengetahui dan memahami pengaruh langsung kompetensi 
mengajar guru terhadap motivasi berprestasi siswa SD kelas VI.

b) Untuk mengetahui dan memahami pengaruh tidak langsung kompetensi mengajar guru terhadap motivasi berprestasi melalui konsep diri siswa SD kelas VI.

c) Untuk mengetahui dan memahami pengaruh langsung pola asuh orang tua terhadap motivasi berprestasi siswa SD kelas VI.

d) Untuk mengetahui dan memahami pengaruh tidak langsung pola asuh orang tua terhadap motivasi berprestasi melalui konsep diri siswa SD kelas VI.

e) Untuk mengetahui dan memahami pengaruh konsep diri terhadap motivasi berprestasi siswa SD kelas VI.

\section{METODOLOGI PENELITIAN}

Penelitian ini merupakan penelitian korelasional yang dilaksanakan di SD Islam ANNIZAM， SD BODHICITTA， SD PARULIAN 2, SD PADAMU NEGERI, SD NEGERI 066665, SD NEGERI 066667, dan SD NEGERI 068074. Penelitian ini termasuk kedalam penelitian korelasional dengan pendekatan statistic dependent method.

\section{a. Variabel Penelitian}

Variabel penelitian ini adalah konsep diri (sebagai variabel endogenus) terhadap kompetensi mengajar guru dan pola asuh orang tua (variabel eksogenus), dan Motivasi Berprestasi (sebagai variabel endogenus) terhadap kompetensi mengajar guru dan pola asuh orang tua(sebagai variabel eksogenus).

\section{b. Teknik Pengumpulan Data Penelitian \\ Dalam pengumpulan data} penelitian ini dilakukan dengan menggunakan alat ukur skala psikologi.

\section{c. Teknik Analisis Data}

Teknik analisa data yang digunakan untuk pengujian hipotesis dalam penelitian ini yaitu uji path analysis. Untuk mempermudah pemahaman teknik analisis jalur maka hubungan kausal dari $X_{1}$ dan $X_{2}$ ke $X_{3}$ dan dari $X_{3}$ ke $Y$ dapat digambarkan sebagai berikut:

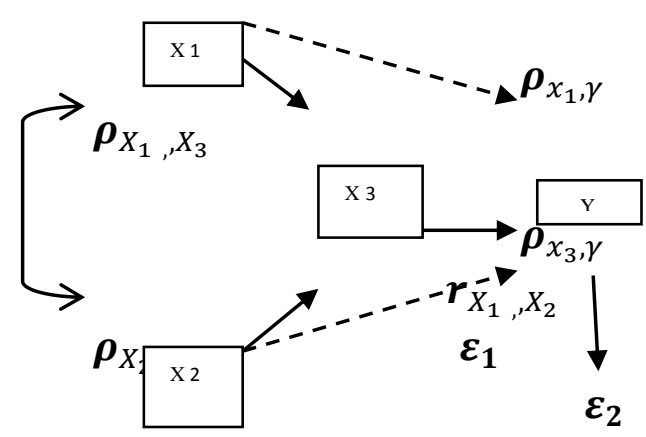

$$
\begin{aligned}
& \begin{array}{l}
\text { Gambar Analis Jalur } \\
\text { Keterangan: }
\end{array} \\
& \longrightarrow=\begin{array}{c}
\text { pengaruh } \\
\text { langsung } \\
\text { pengaruh tidak } \\
\text { langsung }
\end{array} \\
& \text { Dimana: } \\
& \text { X1= Kompetensi mengajar guru } \\
& \mathrm{X} 2=\text { Pola Asuh Orang Tua } \\
& \mathrm{X} 3=\text { Konsep diri } \\
& \mathrm{Y}=\text { Motivasi Berprestasi }
\end{aligned}
$$


Pada gambar diatas terdapat dua buah sub struktur. Pertama sub struktur yang menyatakan hubungan kausal dari $X_{1}$ dan $X_{2}$ ke $X_{3}$ dan substruktur kedua

mengisyaratkan hubungan kausal dari $X_{1}, X_{2}$ dan $X_{3}$ ke Y. Sub-struktur pertama, $X_{1}$ dan $X_{2}$ merupakan variabel eksogenus, $X_{3}$ sebagai endogenus dan $\varepsilon_{1}$ sebagai variabel residu.

Persamaannya adalah sebagai berikut:

$$
\begin{aligned}
& r_{13}=p_{31}+p_{32} r_{12} \\
& r_{23}=p_{31} r_{12}+p_{32}
\end{aligned}
$$

Pada sub struktur kedua $X_{1}, X_{2}$ dan $X_{3}$ merupakan variabel eksogenus, $\mathrm{Y}$ sebagai variabel endogenus dan $\varepsilon_{2}$ sebagai variabel residu. Persamaan sub strukturnya sebagai berikut:

$$
\begin{aligned}
& r_{14}=p_{41}+p_{42} r_{12}+p_{43} r_{13} \\
& r_{24}=p_{41} r_{12}+p_{42}+p_{43} r_{23} \\
& r_{34}=p_{41} r_{13}+p_{42} r_{23}+p_{43}
\end{aligned}
$$

$$
\begin{aligned}
& \text { Hitung } R^{2} x_{3}\left(X_{1}, X_{2}\right) \text { yaitu } \\
& \text { koefisien yang menyatakan } \\
& \text { Determinasi total } X_{1} \text { dan } X_{2} \text { terhadap } \\
& X_{3} \text { - Hitung } \rho_{x_{3} \varepsilon} \quad \text { berdasarkan } \\
& \text { rumus : } \\
& \rho_{x_{3} \varepsilon}= \\
& \sqrt{1-R_{x_{3}}^{2}\left(X_{1}, X_{2}\right)} \\
& -\quad \text { Hitung } R^{2}{ }_{y\left(X_{3}\right)} \\
& R^{2}{ }_{y\left(X_{3}\right)}=\rho_{y x_{3}} X_{3} \\
& \text { Dimana } \rho_{y x_{3}}=r_{y x_{3}}
\end{aligned}
$$

\section{HASIL PENELITIAN DAN PEMBAHASAN}

Sebelum dilakukan analisa data maka terlebih dahulu dilakukan uji asumsi penelitian, yaitu: Uji Normalitas dan Uji Linearitas.

Pada pengujian linearitas digunakan diagram pencar (scatter diagram) untuk melihat kecenderungan sebaran data dari masing-masing variabel bebas (eksogenous) terhadap variabel terikat (endogenous). Jika masingmasing hubungan variabel bebas dengan variabel terikat cenderung linier maka dapat diasumsikan bahwa hubungan variabel bebas dengan variabel terikat cenderung linier.

\section{a. Uji Multikolinearitas}

Menurut Sarwono (2006) apabila nilai VIF tolerance yang lebih kecil dari 5 menunjukkan tidak adanya multikolinearitas antar variabel eksogen. Dari tabel diatas dapat dilihat nilai VIF sebesar 1,900 sehingga dapat diasumsikan bahwa tidak terjadi multikolinearitas antar variabel eksogen(antara variabel kompetensi mengajar guru dan pola asuh orang tua)

\section{b. Uji Normalitas}

Uji normalitas dilakukan dengan menggunakan Kolmogorov Smirnov. Menurut Kerlinger (1990) variabel dikatakan terdistribusi normal apabila $\mathrm{p}>0,05$. Berdasarkan data dari tabel dibawah dapat dilihat untuk 
variabel kompetensi mengajar guru diperoleh signifikansi sebesar 0,229 ( $p>0,05)$, ini menunjukkan bahwa populasi terdistribusi normal. Untuk variabel pola asuh orang tua diperoleh signifikansi sebesar 0,09 ( $>0,05$ ), ini menunjukkan bahwa populasi terdistribusi normal. Untuk variabel konsep diri diperoleh signifikansi sebesar 0,126 ( $>0,05)$, dan variabel motivasi berprestasi diperoleh signifikansi sebesar $\quad 0,215 \quad(p>0,05) \quad$ ini menunjukkan bahwa populasi terdistribusi normal.

\section{c. Uji Liniaritas}

Pada pengujian linearitas digunakan diagram pencar (scatter diagram) untuk melihat kecenderungan sebaran data dari masing-masing variabel bebas (eksogenous) terhadap variabel terikat (endogenous).

Scatterplot

Dependent Variable: MotivasiBerprestasi

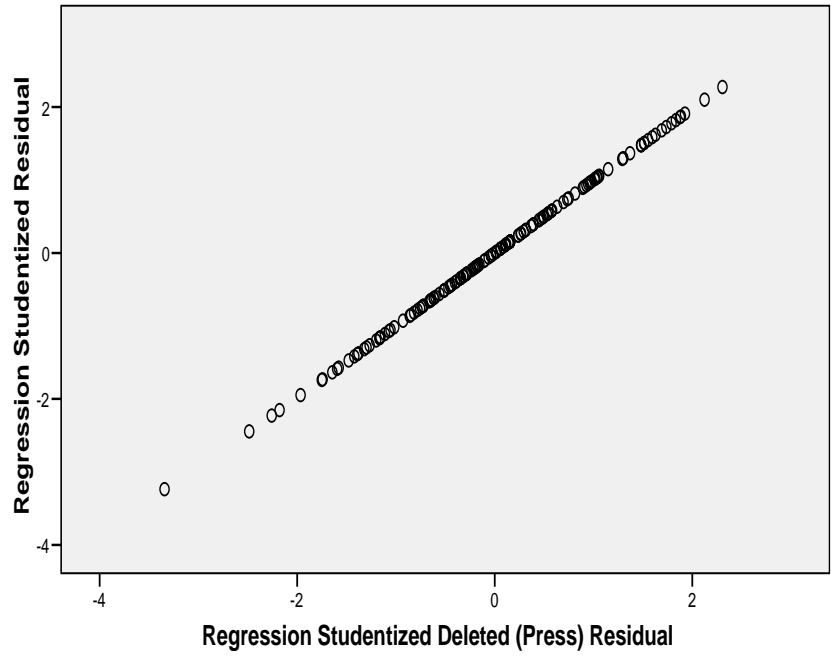

\section{d. Menghitung Pengaruh}

Langsung (Direct effect atau DE)

Untuk menghitung pengaruh langsung atau DE, dengan formula sebagai berikut:

a. Pengaruh $X_{1}$ (Kompetensi Mengajar guru) terhadap $X_{3}$ (Konsep Diri)

DE $3.1 \mathrm{X} 1 \longrightarrow \mathrm{X} 3=0,560$

b. Pengaruh $X_{2}$ (Pola asuh Orang Tua) terhadap $X_{3}$ (Konsep Diri)

$\mathrm{DE} 3.2 \mathrm{X} 2 \longrightarrow \mathrm{X} 3=0,347$

c. Pengaruh $X_{1}$ (Kompetensi Mengajar guru) terhadap $Y$ (Motivasi Berprestasi)

DE 4.1 X1 $\longrightarrow \mathrm{Y}=0,408$

d. Pengaruh $X_{2}$ (Pola asuh Orang Tua) terhadap $Y$ (Motivasi Berprestasi)

$\mathrm{DE} 4.2 \mathrm{X} 2 \longrightarrow \mathrm{Y}=0,266$

e. Pengaruh $X_{3}$ (Konsep Diri) terhadap $Y \quad$ (Motivasi Berprestasi)

$\mathrm{DE} 4.3 \mathrm{X} 3 \longrightarrow \mathrm{Y}=0,20$

\section{e. Menghitung Pengaruh Tidak} Langsung (Indirect Effect).

Untuk menghitung pengaruh tidak langsung atau IE digunakan formula sebagai berikut:

a. Pengaruh $X_{1} \quad$ (Kompetensi Mengajar guru) terhadap $Y$ (Motivasi Berprestasi) melalui $X_{3}$ (Konsep Diri)

$\mathrm{IE} 1.4 .3 \mathrm{X} 1 \longrightarrow \mathrm{X} 3 \longrightarrow \mathrm{Y}$ $=(0,408 \times 0,204)=0,083$ 
b. Pengaruh $X_{2}$ (Pola asuh Orang Tua) terhadap $Y$ (Motivasi Berprestasi) melalui $X_{3}$ (Konsep Diri)

$\mathrm{IE} 4.2 \mathrm{X} 2 \longrightarrow \mathrm{X} 3 \longrightarrow \mathrm{Y}=$ $(0,266 \times 0,204)=0,054$

\section{SIMPULAN DAN SARAN}

Berdasarkan hasil analisis dan pembahasan, maka penulis dapat menarik kesimpulan sebagai berikut:

a. Pengaruh $X_{1}$ (Kompetensi Mengajar guru) terhadap $Y$ (Motivasi Berprestasi) secara langsung sebesar $0,408=$ 40,8\%. Kompetensi mengajar guru berpengaruh langsung terhadap motivasi berprestasi, ini terlihat pada nilai sig. $0,000 .(0,000 \leq 0,05)$.

b. Pengaruh $X_{2}$ (Pola asuh Orang Tua) terhadap $Y$ (Motivasi Berprestasi) secara langsung sebesar $0,266=26,6 \%$. Pola asuh orang tua berpengaruh langsung terhadap motivasi berprestasi, hal ini terlihat pada nilai sig. 0,000 . $(0,00 \leq 0,05)$. c. Pengaruh tidak langsung $X_{1}$ (Kompetensi Mengajar guru) terhadap $Y \quad$ (Motivasi Berprestasi) melalui $X_{3}$ (Konsep Diri) sebesar 0,083 $=8,3 \%$.

d. Pengaruh tidak langsung $X_{2}$ (Pola asuh Orang Tua) terhadap $Y \quad$ (Motivasi Berprestasi) melalui $X_{3}$ (Konsep Diri) sebesar 0,054 = $5,4 \%$.

e. Pengaruh $X_{3}$ (Konsep Diri) terhadap $Y \quad$ (Motivasi Berprestasi) sebesar 0,204= 2,04\%.

f. Besarnya pengaruh variabel diluar X1 (kompetensi mengajar guru) dan $X_{2}$ ( pola asuh orang tua) terhadap konsep diri sebesar $0,545=54,5 \%$.

g. Besarnya pengaruh variabel diluar X1 (kompetensi mengajar guru) dan $X_{2}$ ( pola asuh orang tua) terhadap motivasi berprestasi sebesar $0,599=59,99 \%$. 


\section{DAFTAR RUJUKAN}

Chaplin, J. P. 2004. Kamus Lengkap Psikologi. Jakarta: PT. Raja Grafindo Persada.

Hurlock, Elizabeth. B. 1999. Psikologi Perkembangan Suatu Pendekatan Sepanjang Rentang Kehidupan. (Edisi Kelima). Jakarta: Erlangga.

Sobour, Alex. 2003. Psikologi Umum dalam Lintasan Sejarah. Bandung: CV Pustaka Setia.

Sudjana, Nana. 2003. Perencanaan Pengajaran. Jakarta: P2LPTK.
Undang-Undang Republik Indonesia Nomor 20 Tahun 2003. Sistem Pendidikan Nasional. Kementerian Pendidikan Nasional.

Uno, Hamzah B. 2009. Teori Motivasi dan Pengukurannya. Jakarta: Bumi Aksara.

Zaini, Hisyam., Munthe, Bermawy,. dan Aryani, Sekar Ayu. 2000. Strategi Pembelajaran Aktif. Yogyakarta: CTSD Institut Agama Islam Negeri Sunan Kalijaga. 
